\title{
Capitalist Threads: Engels the Businessman and Marx's Capital
}

Tiago Mata (University College London) t.mata@ucl.ac.uk

Robert Van Horn (University of Rhode Island) rvanhorn@uri.edu

\section{Acknowledgements:}

We express our gratitude to Norbert Mundorf, Richard McIntyre, Merle Krueger and Regina Roth. We graciously thank the University of Rhode Island College of Arts and Sciences and Hope and Heritage Foundation and the University of Rhode Island Center for Humanities for funding translation work. Mata's research has received funding from the European Research Council under the European Union's Seventh Framework Programme (FP7/2007-2013), grant agreement nº 283754. 


\section{Capitalist Threads: Engels the Businessman and Marx's Capital}

\section{Introduction}

"For the last time," with a shout of triumph and relief, Friedrich Engels left home for his final day at the firm of Ermen \& Engels. Visiting Manchester, Eleanor Marx, the youngest daughter of Karl Marx, recorded his joyous return, crossing a field while "swinging his stick in the air and singing, his face beaming" (Kapp 1972, 112). It was late June of 1869; Engels was 48 years old. Eleanor Marx's witnessing of Engels's release from the bond of commerce appears in all of his biographies. The message of the anecdote is that Engels' joy that day was a measure of the agony he endured during his career as manufacturer. Evidently, his calling was elsewhere. Engels found happiness when he wrote on military history and strategy and pursued the cause of socialism and revolution. The most recent biography insists that he took greater delight from chasing foxes than from chasing profits (Hunt 2010).

Between 1850 and 1870, Engels led a double life. In his two decades in Manchester Engels held two addresses, one official to meet business partners and his family, the other where he lived with the Burns sisters (Mary and Elisabeth) and kept company with exiled revolutionaries, hosting Marx on his occasional visits (Whitfield 1988,7$) \cdot{ }^{1}$ Scholarship has been drawn to the radical side of this double life. Part of the explanation for this attention is lack of evidence. Writing in the early 1930s, Engels's first and foremost biographer, Gustav Mayer, observed that there was "no exact information on [his]

1 Whitfiled $(1988,38)$ lists three official addresses at Great Ducie St., Thorncliffe Grove and Dover Street, and possibly seven other unofficial addresses. 
commercial duties" to Ermen \& Engels" (Mayer 1936, 46). Since Mayer's there have been numerous other biographies, a complete set of correspondence and personal papers of Marx and Engels is undergoing publication as the Marx-Engels Gesamtausgabe (MEGA) and Wuppertal historians, in particular Michael Knieriem, have revealed the business history of the Engels family. On the basis of this evidence we are now much better sourced to reconstruct Engels's business life.

In this essay, we begin by reviewing the company history of Ermen \& Engels and the status of Manchester as the hub of the cotton industry in the mid$19^{\text {th }}$ century. We argue that Engels was a merchant and an intelligencer. Although Engels had knowledge of all aspects of cotton spinning, his primary charge was to liaise with customers and suppliers, hence he had a detailed understanding of products and a vantage point upon the movements of goods, orders and prices.

We claim Engels's unhappy Manchester years left an imprint on the development of Marxist political economy. We argue that his insight into the most capital-intensive global commodity of the 1850 s and 1860 s, sold in world markets and sourced from raw materials from the New World and India, shaped key ideas and themes of Karl Marx's Capital Volumes I and II. The statistical insights Engels gleaned from his perch in Manchester became prominent illustrations of advanced industry in Capital. But Marx did not only call upon Engels to exemplify an independently developed theoretical point. On matters such as machinery depreciation and reinvestment, Marx could not rely on theory alone and sought out Engels' business acumen for guidance. 
Alongside our examination of the substantive contributions by Engels to the writing of Capital, we also remark upon thematic overlaps between the library toil of London and the warehouse labors of Manchester. In prying into the structures of industrial capitalism, Marx's intellectual project was to rid political economy from the self-serving ideology of the bourgeoisie and rebuild it from more robust foundations. Thus Marx often took as his point of departure the views and beliefs of capitalists and their economists and he adopted core beliefs of Manchester as essential features of industrial capitalism. First among these was a conception of capitalism as a unified world market, and related to this conception that it was under a constant threat of overproduction and would bring with it collapse if the pace of production was interrupted. These elements were uncontroversial in Engels' experience of Manchester and of Ermen \& Engels and a fundamental element of his legacy in political economy.

\section{Family Partnerships and Business Intelligence}

Manchester had grown spectacularly in the 1820 s and 1830 s as the commercial center of Lancashire, and by the time Engels arrived, the city had already supplanted London as financial center for the cotton industry. ${ }^{2}$ The town was "a magnet for those wishing to decipher the meaning of industrialization" who could observe "its stark contrasts of misery and Midas-like riches" (Hunt 2010, 79). Manchester was an icon, earning the sobriquet of "cottonopolis."

Engels lived in Manchester from 1842 to 1844 . His first stint at Ermen \& Engels was, as his father saw it, part of his practical instruction in commerce (Knieriem 1980). What Engels committed to paper from that visit was not the

\footnotetext{
2 Engels's first visit to Manchester was actually in 1838, aged 18, accompanying his father.
} 
portrait of affluence but a compelling indictment of its counterpart. Engels's remarkable text, Condition of the English Working Class, has fascinated scholars and activists since its publication. We have several accounts that use the Condition to reconstruct the lived experience and the intellectual outlook of the young Engels. However, these accounts do not help us to follow Engels beyond 1844 and shed no light on his activities in the 1850s and 1860s. To appreciate the character of Engels' affairs and his knowledge of business we first turn to a history of the firm Ermen \& Engels and describe the Manchester of the panic of 1857 and of the "cotton famine".

Throughout the nineteenth century, the cotton industry in Britain as in Germany was characterized by private partnerships reliant on family networks. Located in the regions of Lancashire and the Rhineland, the starting capital for modern industry came from a cluster of families already proficient in textile manufacture (Rose 2000, Kisch 1959). Ermen \& Engels exemplified this pattern. The Engels clan had produced textiles for more than a century before Ermen \& Engels was founded. The first enterprise, named Caspar Engels Söhne was created in 1747 in Barmen (Barmen together with Elberfeld now form the city of Wuppertal). At the start of the $19^{\text {th }}$ century, the Engels family owned 80 of the 179 mills in the city. In the 1830s the firm was jointly managed by three brothers, Caspar III, August, and Friedrich's father, also called Friedrich. It is around this time that Friedrich senior becomes acquainted with Peter Ermen. ${ }^{3}$ Peter with his brothers Godfrey and Anton had a firm named Ermen Brothers, consisting of a couple of small spinning mills near Salford, in the outskirts of Manchester. Peter

\footnotetext{
3 Peter was born in Holland in 1802 and moved with his family to Hachenburg in Germany as a child. In 1820 he emigrated to England and was employed as a foreign agent for a yarn trading company, "Sheldon \& Co." of Manchester. Six years later he set up his own mill.
} 
and Friedrich meet in 1832 when the latter visited England and they began planning for a new business venture. Friedrich senior withdrew from the family firm in May 1837 and joined in partnership with Peter creating Ermen \& Co, renaming it Ermen \& Engels the following year (in fact these were two legally distinct but identically named firms in England and in Prussia) (Knieriem 1986). Pooling their capital, they built Victoria Mill, in Eccles, six miles from Manchester; and another mill in Barmen, eventually adding mills in Engelskirchen, and Salford (Henderson 1971).

The pooling of capital and the twin traditions in textile manufacturing may suggest that England and Germany were much alike but it was far from it. The crux of the deal was that Germany supply some of the finance and England supplied the know-how, access to raw materials and equipment. In 1840, Friedrich Senior petitioned successfully the Prussian Finance Ministry to be exempt from duties in importing English machinery. Thereafter, the Engels's Rhineland mills became an "English operation" reliant on English machines and on a English scale (Illner 2011). The mills used a mode of production that was still unusual in Germany and was met with praise and criticism. In 1844, the firm was invited to a industry show in Berlin to showcase its operations. In 1852, it was reprimanded by the local government for the long work hours of its child employees (Knieriem 1986).

The other crucial difference between the two branches of Ermen \& Engels was that while Lancashire produced for a world market, the Rhineland mills labored to clothe Prussia under the shelter of tariffs. Lancashire with its commercial and financial hub at Manchester was a node in a vast imperial and commercial infrastructure exchanging goods, capital, people and information 
that reached outward to Liverpool and London and beyond to shores all over the globe. The Rhineland lacked such reach but could partake in it through English partnership. Thus, Engels diurnal duties at Ermen \& Engels consisted of closely watching world markets often reporting back his observations to father and brothers, and as we will show, that information was also a subject of his letters to Marx.

Alongside these asymmetries, Manchester was cause for a different sort of worry. Engels senior was concerned about the return to his investment. When the Engelskirchen mill opened, Anton Ermen moved to Germany to safeguard the interests of his family. But in England there was no agent of the Engels family. The fact that the Manchester offices of Ermen Brothers and Ermen \& Engels overlapped in personnel and location augmented the suspicions of Friedrich senior. He believed that the Ermens were diverting his capital to the benefit of the firm Ermen Brothers.

The breakdown of trust between the partners sealed Friedrich Junior's return to business. In 1849, he was seeking reconciliation with his family. After some notorious activity in the revolutionary stirrings of the year before, he was forced to flee Prussia fearing imprisonment. Propitiously for Engels, his father believed that a feud between Peter and Godfrey Ermen treated the profitability of the firm and that the Ermens were misappropriating funds. In 1850, Engels joined the English firm as a clerk to represent his father's interests, and drawing a salary from Germany. For two years he kept watch on the commercial dealings of the Ermen brothers. Engels's father may have doubted his son's political reasonableness and his piety, but he trusted him to be his Manchester intelligencer. Engels gloated to Marx: “[M]y old man is enchanted with my 
business letters and he regards my remaining here as a great sacrifice on my part." ${ }^{4}$ Contrary to this belief that he had fooled his father, Friedrich senior had set his son on this course as early as 1837. The year Ermen \& Engels was formed was also the year he took his first born out of the Gymnasium and imposed on him an apprenticeship in international commerce.

Engels examined the company books at the office during "dinner hours" so he would not be discovered. ${ }^{5}$ A month after he started, he reported to Marx that "little remains save the very involved task of comparing the prices at which Ermen Bros have been selling to us with the current prices on each occasion." A few days after he wrote this, he sent his father the complete accounts of Ermen Bros for $1849 / 50$, so that "he may see how these gentlemen carry on business with his capital." 6 For years he continued to report to his father on the profit loss of the business with great minutia. ${ }^{7}$ On one such occasion in 1860 , Gottfried Ermen found out that Engels took the books home and was incensed. ${ }^{8}$ The secrecy and protectiveness of the accounts in 1850 as in 1860 suggests that business was opaque even for the inner circle of partners and clerks. Distrust was rife about discriminatory pricing, and about misuse of funds.

The period of fraternal dispute ended in 1852 when Engels's father took Godfrey's side and forced Peter into retirement. As part of their deal, the firm of Ermen Brothers was dissolved. To ensure he would remain in Manchester, Engels convinced his father to secure his employment as a "corresponding clerk

\footnotetext{
${ }^{4}$ Friedrich Engels to Karl Marx , Marx and Engels Collected Works [henceforth MECW], v. 38, \#147, February 26, 1851.

5 Engels to Emil Blank, MECW, v. 38, \#127, December 3, 1850. Engels also complained to Emil Blank that when Peter Ermen was around more, it was even more difficult to examine the books. ${ }^{6}$ Engels to Blank, MECW, v. 38, \#127, December 3, 1850.

${ }^{7}$ We don't have Engels's letters to his father but the replies testify to the detail of the reports. Father and son drew yearly comparisons and puzzled over the accounts. See Friedrich Engels to Friedrich Engels, Marx-Engels-Gesamtausgabe [henceforthe MEGA], III/7, December 20, 1853. ${ }^{8}$ Engels to G. Ermen, MECW , v, 41, \#56, April 19, 1860.
} 
and general assistant" (Jenkins 1951, 10). Engels began to earn a secure income from the English firm, and no longer needed to argue with his father over his financial needs. His contract of 1852 stipulated that he "duly observe lawful directions of Godfrey Ermen .... Shall keep time and regular accounts... All payments, receipts, sales orders, transactions, matters and beings." Although Peter was the founder, Godfrey had become the dominant figure in the firm. In fact, the firm owed its best selling product: “Godfrey Ermen’s Patent diamond thread" to his invention of a device to clean thread. The firm's office was at 7 Southgate, Deansgate, which Engels described to his mother as a "gloomy room in the warehouse, looking out on to the courtyard of an ale-house." 9 The office and warehouse were several miles away from the mills, ${ }^{10}$ and this location is consistent with our claim that Engels's responsibilities lay with the commercial affairs and bookkeeping of the firm. The surviving letters by Gottfried Ermen to Engels, written when Engels was travelling in Europe or convalescing from illness, fill in this picture. The letter's recurring theme was concern over customers, both in a lack of new orders or in payments past due. One of Engels's primary roles was to seek new orders and make sure they we paid on time. ${ }^{11}$ In 1860 Ermen \& Engels in England had an estimated 60,000 pounds in capital and 800 employees (Henderson 1971). The 1861 census records that

\footnotetext{
${ }^{9}$ Friedrich Engels to Elisabeth Engels, MECW, v. 43, July 1, 1869.

10 That Engels' primary responsibility was with ordering and book keeping does not imply he was not knowledgeable of the operations and conditions in the Mills. Certainly in his first period at Manchester Engels visited Victoria Mills, the main site of Ermen \& Engels business, and reported upon it vividly in his The Condition of the Working Class in England. In a much reproduced passage we read that "in the throstle room of the mill at Manchester in which I was employed, I do not remember to have seen one single tall, well built girl; they were all short, dumpy and badly formed...".

11 Gottfried Ermen to Friedrich Engels, MEGA III/8, October 25, 1857; Charles Roesgen to Friedrich Engels, MEGA III/8, October 27, 1857. The letters also make clear that all prices were set by the Ermen brothers, see Gottfried Ermen to Friedrich Engels, MEGA III/9, November 3, 1858.
} 
Godfrey Engels employed 150 males and 525 females for spinning, 27 males and 58 females for bleaching, and 28 males and 3 boys for dyeing (Whitfield 1988). Ermen \& Engels was a medium sized firm in the context of Lancashire industry. It was among a select group specialized in spinning cotton thread for sewing and hosiery-knitting. This specialized branch of the industry did well in the 1850s and 1860s thanks to rising household demand for its products.

The most notable institution of Manchester's dominion over cotton commerce and the site Engels sought for deals and information was the Exchange. The Exchange was built in 1804 for convenience of merchants seeking shelter from the inclement weather, and willing to pay for better surroundings than taverns or coffeehouses. In 1841 it underwent a major extension and was completely rebuilt in 1867-1874 as Engels was retiring, at each rebuilding it gained in majesty and comfort. The Exchange was a private club with paid annual subscription and because it was a for profit institution promising an attractive dividend to its founders (5\% to $7 \%$ ), it had low barriers to entry. In 1850 it had 2678 subscribers, by 1860 there were 4209, and by 1869 there were 6521 members. When Engels became member of the Exchange, in 1854, the Marxes rejoiced at the news as omen of growing power and riches. ${ }^{12}$ But by then the membership was no longer made up primarily of owners; numerous agents, salesmen and representatives, like himself, had joined in order to stay abreast of changes in the markets and use the Exchange to make deals.

The Exchange was the clearing house of Manchester intelligence. One of its histories, in a self-promotional flight of fancy, claimed that on the Exchange "there was a more detailed knowledge of every corner of the earth than in any

\footnotetext{
12 Marx to Engels, MECW, v. 39, \#241, September 2, 1854.
} 
other room in the world. To sell a yard of calico in a small South American state you had to know (and understand) precisely the political and mercantile pulse of the place. To get this sort of information you depended on a string of intrepid foreign emissaries who would send word back to the Exchange"(Scott 1976, 267). On Tuesdays during "High 'Change," its monumental hall would fill with thousands of gentlemen in hats pacing and whispering deals. Overlooking the assembly of dealers were the posted prices of cotton at the Liverpool brokerage. The Exchange also had an extensive library of newspapers and other trade information, and for a long time had a Post Office on site (Rose 2000)

Although he "spoke contemptuously of hunting for customers on the ‘confounded' exchange” (Jenkins 1951, 10), Engels had a front row seat (although he likely had to stand, there was no seating in the hall) to watch the movement in moods, prices and volumes traded, and thus infer the state of the market and its prospects. The Exchange was a source of excitement and insight that animated some of his correspondence with Marx. One representative market report by Engels in 1858 read: "Business here is tremendously good; for the past 6 weeks the spinners have been making $1 \mathrm{~d}$ à $1 \frac{1}{1 / 4} \mathrm{~d}$ more per pound on coarse and medium counts than for the past 3 years and-quite unprecedented this-the local market in yarn rose $1 \mathrm{~d}$ before the Liverpool chaps were able to get another $1 / 4 \mathrm{~d}$ for cotton."13 In his reports, Engels speculated about close and distant futures. The excerpted 1858 letter came after the severe crisis of 1857 and Engels wondered if the spurt of prosperity was not giving encouragement to another bubble of overproduction.

\footnotetext{
13 Engels to Marx, MECW, v. 40, \#184, October 7, 1858.
} 
Engels's commercial knowledge, his fluency in foreign languages, his ease in writing, his evident confidence with accounting, were assets for an agent in a firm with an international clientele. He worked exceptionally hard, occasionally remarking to Marx about periods of overwork. For example, writing that "Whenever I think I have caught up to some extent with my commercial rubbish, I discover a whole pile of unsuspected arrears, am overrun by chaps, have to reply to hundreds of business queries on behalf of my old man and pander to fresh whims of Mr. Gottr.'s."14 Once when Engels was overworked and ill, Marx wrote him: "Surely it is not your ambition to go down to posterity as one who sacrificed himself on the altar of Ermen \& Engels' office?"15 The demands of the job animated a deep antipathy towards the Ermen kin. Engels would write in anger that "good Gottfried is indeed a breech-wetter,"16 and another time referred to Peter Ermen as a "tree frog." 17 Engels' feelings are not surprising. He had reasons to doubt the brothers' integrity, and in the early years the pair hounded and pestered him as an unwanted intruder. ${ }^{18}$ Significantly, as we will see below, despite Engels' disdain towards the Ermens and his occupation, Marx had to rely on Engels and his co-workers to gather information for Capital.

In spite of his persistent complaints, Engels took pride in his competent diligence. When in 1858 Marx urged him to skip work to finish a pamphlet, Engels elected to cut on sleep to write rather than to feign illness. His commitment to the toil of commerce was surely reinforced by the freedom he was able to buy Marx as his unfailing and unquestioning patron. A further

\footnotetext{
14 Engels to Marx, MECW, v. 40, \#49, March 11, 1857.

15 Marx to Engels MECW, v. 40, \#79, July 14, 1857.

${ }^{16}$ Engels to Marx, MECW, v. 41, \#247, September 9, 1862. Marx once called Gottfried a bootlicker, in Marx to Engels, MECW, v. 41, \#176 June 19, 1861.

17 Engels to Marx, MECW, v. 38, \#192, July 30, 1851.

18 Engels to Marx, MECW, v. 38, \#128, December 17, 1850.
} 
contributing factor was the affection he nurtured for his family, first of all for his mother with whom he maintained a lifelong devoted correspondence.

The status of Engels within the firm changed as a result of his father's sudden death in 1860. Engels's siblings plotted successfully to exclude the eldest son from the bulk of the inheritance. Engels received 10,000 pounds from his father's estate, while the brothers took control of the mills in Prussia. ${ }^{19}$ With his inheritance, Engels bought himself a partnership with Godfrey Ermen that preserved Ermen \& Engels in name. The negotiations however were not amicable and Engels had a nervous breakdown as a result. He felt abandoned by his family and hostage to Godfrey's hard bargaining. Eventually, one of his brothers travelled to Manchester to broker the deal with Godfrey. ${ }^{20}$ Even so, it took four years before Godfrey committed to paper what they had agreed, only on $30^{\text {th }}$ June 1864, finally giving Engels the income security he desired. ${ }^{21}$

When in 1860 the Anglo-German partnership ended, the Engelskirchen and Barmen mills remained with the Engels family. Significantly, even though there was no formal relationship between the two families, they continued to trade and the information flow was uninterrupted with Friedrich writing occasional reports on the cotton market to his siblings and making enquiries on

\footnotetext{
19 The role played by the nuclear family in capitalism was a subject Engels revisited later in his life, in Origin of the Family, after coming across a set of ethnographic notebooks by Marx. Engels concluded that the family was indispensable for capitalism's development as regulator of property relations. Engels was writing from personal experience.

20 To outvote Engels, Godfrey re-introduced his brother Anton into the firm. Anton was however never more than a perfunctory figure, and most often less than, as he allegedly "turned the office into a pub." Around this time, Godfrey also resurrected Ermen Brothers, placing his nephew Henry as manager of the Bridgewater Mill in Pendlebury. (Whitfield 1988).

${ }^{21}$ From 1852 when he became an employee of Ermen \& Engels, Engels received $£ 100$ a year and 5 per cent of the profits in the first four years, $71 / 2$ per cent in the second four, and 10 per cent in the next four. When he became partner in 1864, the share of profits rose to 20 per cent. Upon retirement, Engels withdrew 7,500 pounds and a further 4,964 pounds $16 \mathrm{~s} 4 \mathrm{~d}$ from the company. (Mayer 1936, 136).
} 
their behalf. ${ }^{22}$ As before, he acted as occasional purchasing agent and

intelligencer for the family. He fielded questions about machinery sating his

family's eagerness to copy whatever the English were doing. In a letter to his

brother Emil, Engels gave a detailed description of how the cotton machinery

functioned so as to keep him abreast of any innovation. Engels was confident

that his description should be enough for his brother to make improvements on

his own. He explained that continuous improvement and tinkering was the norm

at Ermen \& Engels. ${ }^{23}$

For Engels's family Manchester was their road to riches, to him it was

income security. They owed much to the town, its special mode of production

and global reach. Manchester was the model setter for the factory system, and

all else that accompanied it. As the center of their world, Manchester influenced

Engels' reading of the pulse of capitalism, how he monitored world markets and

how he took note of its working class. Perhaps unsurprisingly, in Marxist

political economy Lancashire cotton became the icon for advanced industry.

\section{Cotton Industry Analyst: Engels as Marx's Informant}

Engels provided Marx with an inimitable understanding of the cotton industry.

None of Marx's other correspondents wrote to him about the cotton industry

with the sophistication and prudence of Engels. Marx recognized the importance

\footnotetext{
22 See for instance the letter by Hermann Engels to Friedrich Engels, MEGA III.12, January 3, 1863, when his brother asks him to make inquiries of a shipment of cotton ordered by the German firm. ${ }^{23}$ Engels's brother wanted him to be a purchasing agent for machinery but Engels excused himself. Although Engels had a good grasp of pricing and had been kept informed of the family purchases, he was not directly involved in those deals. The best practice at Ermen \& Engels was to attempt most improvements in house and only for major works to contract a machine builder. See Engels to Emil Engels, MECW, v. 40, \#303, November 16, 1859. Engels also provided information about the machinery to Herman Engels; see also v. 42, \#291, Engels to Herman Engels, November 28, 1867. Similarly, he had also written reports of factory practices to his father, who in 1854, charged him to find out how Ermen \& Engels printed their cards (that accompanied the thread), see Friedrich Engels to Friedrich Engels, MEGA III/7, May 16, 1854.
} 
of Engels's perspective, writing about the European wide convulsions in credit and goods makers, he noted that "your information about conditions in Manchester is of the greatest interest to me, the newspapers having chosen to draw a veil over them."24 Interestingly, Engels would write Marx in detail about the cotton industry, and Marx would almost invariably say little or nothing in reply. In the rare instances when they entered in discussion, Engels would better Marx showing his richer understanding.

A dominant sentiment in Engels's letters to Marx about cotton capitalism was anxiety. Engels's letters conveyed that the first factor of uncertainty was the cotton crop, which was subject to the vicissitudes of weather and in this period to civil war blockade in America. Profitability occurred on a knife's edge of panicky inventory management, volatile price changes, discretionary accounting, and family feud. A firm's margins relied on its successful calculations and negotiations into an uncertain future and timely delivery to clients. The greatest threat, as Engels saw it, was the uncontrolled power of production. Unchecked the cotton industry could bankrupt itself with overproduction.

The letters exchanged between Engels and Marx provide the best way to grasp how Engels helped Marx grasp Manchester capitalism. Engels often wrote Marx reports in the style of a modern day investment analyst. The following is representative:

The minor panic in the money market appears to be over, consols and railway share are again rising merrily, money is easier, speculation is still pretty evenly distributed over corn, cotton, steam boats, mining operations, etc., etc. But cotton has already become a very risky proposition; despite what is so far a very promising crop, prices are rising continuously, merely as a result of high consumption and the possibility of a brief cotton shortage before fresh imports can arrive. Anyway I don't

${ }^{24}$ Marx to Engels, MECW, v. 40, \#111, December 8, 1857. 
believe that the crisis will this time be preceded by a regular rage for speculation; if circumstances are favourable in other respects, a few mails bringing bad news from India, a panic: in New York, etc., will very soon prove that many a virtuous citizen has been up to all kinds of sharp practice on the quiet. And these crucial ill-tidings from overstocked markets must surely come soon. Massive shipments continue to leave for China and India, and yet the advices are nothing out of the ordinary; indeed, Calcutta is decidedly overstocked, and here and there native dealers are going bankrupt. I don't believe that prosperity will continue beyond October or November-even Peter Ermen is becoming worried. ${ }^{25}$

In the 1850s and 1860s Marx and Engels' relationship depended greatly on their correspondence. Their labour was letter writing. Engels as a correspondent clerk was writing customers, suppliers and the german branch of the business. Marx as secretary of the Communist League, at the Workingmen's Association, and in the various political exile committees, maintained and expanded epistolary networks. The Royal Mail in England proved a boon during their exile, a letter posted in Manchester before 9 am would reach London on time for a response on the same day. Because of this the two men could carry on an engaging conversation-Engels could share his frustrations about the Ermen brothers, and Marx could convey his financial distress and report on his ill health. When the occasion justified, Engels could provide Marx with daily reports on the cotton industry. Reviewing these letters we can appreciate how Engels to keep abreast of the cotton market drew from multifarious sources —including numerous newspapers, broker reports, conversations in the Exchange, and the views of his business partners.

Marx's knowledge of cotton and Manchester was obtained through the letter exchange with Engels. There is no evidence that Engels enabled Marx to visit the mills of Lancashire and the trading hubs of Manchester. In the early

${ }^{25}$ Engels to Marx, MECW, v . 39, \#83, August 24, 1852. 
years of their friendship and intellectual partnership, Engels and Marx travelled to Manchester and devoted that summer to reading and discussing political economy at the city's library. By contrast to the summer of 1845, Marx's trips to Manchester in the 1850s and 1860s left few impressions on archival documents and memoirs. However, we do know that on several of these occasions, Marx was ailing from physical and mental exhaustion. He joined Engels with the purpose of recovering his health with day-long horseback rides in the Lancashire countryside. Given Engels's double living, it is unlikely that he would have shown Marx the business of Manchester; indeed there is no testimony of any such visits in Marx's published notebooks, and their correspondence gives no indication of this either. When not ailing, in Manchester, like in London, Marx read. ${ }^{26}$

The correspondence shows that Engels claimed expertise on the core aspects of the cotton market and industry. For example, in December 1868, Marx shared what he believed to be an astounding insight based on his reading of a report by Ellison and Haywood, Liverpool cotton brokers whose circulars on the supply of cotton were among the most reputable and found regular publication as a supplement to The Economist. The report noted that in 1862-4 an enormous quantity of cotton was imported and stored in England. Marx observed that the large stock of cotton must have been vital to avoid the collapse of the cotton market during the American Civil War blockade (the (in)famous "cotton famine"). Marx read this not as a case of foresight, but as one of fantastic

\footnotetext{
${ }^{26}$ Only a small part of Marx's notebooks have been published, up to January 1855, but missing September 1851 to September 1853. Of the published notebooks nearly all comprise of excerpts from readings. But perhaps the most significant evidence that Marx was not drawn to make his own observations of mills is that he always referred back to the parliamentary Factory Reports for his graphic depiction of waged labor. On at least one of these trips, Marx participated in the intellectual life by sitting at the meetings of the Royal Institution and hearing discussions about the statistical description of the cotton markets.
} 
luck, exclaiming: "What a fine crash that would have produced if the Civil War had not broken out!"27 The reasoning but most crucially the data, failed to impress Engels. He offered to provide Marx more thorough statistics from the Liverpool Broker Association, objecting " that, to explain things rationally, you must include 1861, when the colossal 4 million crop of 1860 gradually arrived here. How Ellison \& Haywood could omit this is incomprehensible to me, unless the people had a particular business purpose in their statistics." 28 Engels did not clarify what he meant by the "particular business purpose" of Ellison \& Haywood whose business was to inform clients of the supply of cotton. Engels's comments makes clear his self-confident understanding of the cotton market and thereby his ability to help Marx refine his understanding.

Engels's correspondence to Marx about the cotton industry intensified during crisis. With the onset of the 1857 crisis, Engels wrote Marx: "It's capital that you should be collecting material on this crisis. I am sending you another 2 Guardians today. You shall have it regularly, and the Examiner and Times too now and again. I shall also advise you as frequently as possible of everything I learn so that we have a good stock of facts." 29 In November 1857, Engels provided Marx with a plethora of inside information. He colorfully described the Exchange:

The general appearance of the Exchange here was truly delightful last week. The fellows are utterly infuriated by my sudden and inexplicable onset of high spirits. Indeed, the Exchange is the one place where my current dullness is transformed into resilience and bouncing. On top of that my predictions are, of course, always gloomy, which makes the asses doubly furious. On Thursday the situation was at its most dismal, on Friday the gentlemen were mulling over the possible effects of the suspension of the Bank Act and, with cotton rising another 1d., word went

\footnotetext{
27 Marx to Engels. MECW, v.43, \#125, December 9, and Marx to Engels, \#128, December 12, 1868.

${ }^{28}$ Engels to Marx, MECW, v. 43, \#131, December 13, 1868.

${ }^{29}$ Engels to Marx. MECW, v. 40, \#106, November 15, 1857.
} 
round that the worst was over. By yesterday, however, the most delectable despondency again prevailed; all the hosannas had been so much hot air and, since hardly anyone wanted to buy, the market here remained as bad as ever. ${ }^{30}$

He delineated the effects on labor and captured the international scene:

The extension and prolongation of the crisis are also assured. The combination of short time and the silk crisis, which latter has already deprived the vast mass of the silk (hand-loom) weavers of their livelihood, will of itself suffice to ruin the hometrade completely this winter-up till the end of October it was still doing well. The American crisis is playing havoc with the Barmen and Elberfeld smallware manufacturers, the Elberfeld, Krefeld and Lyons silk manufacturers and the German, French and Belgian cloth manufacturers. The smallware manufacturers of Barmen are suffering particularly also due to Bennoch and Twentyman, while Draper, Pietroni \& Co. are causing difficulties in Italy, especially Milan, the Duchies, Bologna, etc.... Never before has any crisis exhausted itself so rapidly and abruptly, and this one, coming after 10 years of prosperity and speculation, is least apt to do so. Nor is there another Australia or California to come to the rescue, while China will be in the doldrums for the next 20 years. ${ }^{31}$

Since understanding the crisis crucially depended upon appreciating the price fluctuations of cotton, Engels prepared a detailed chart on the price changes of Orleans Middling cotton, showing cotton had reached an unprecedented low a couple of days before he wrote Marx. Engels used official reports from an Ermen \& Engels's broker to create the chart. ${ }^{32}$ To Engels the ebb and flow of the markets had more than just office interest, it prefigured revolutionary opportunity. The conclusion of his market analysis to Marx was a call to arms, noting with emphasis that

I must say I feel just as you do. When the bubble burst in New York I grew very restless in Jersey and in the midst of this general downbreak I fell tremendously cheerful. The bourgeois filth of the last seven years has undoubtedly clung to me to some extent; now it will be washed away and I shall become a changed man. Physically, the crisis will do me as much good as a bathe in the sea; I can sense it already. In 1848 we were saying: Now our time is coming, and so in a certain sense it was, but this time it is

\footnotetext{
30 Ibid.

31 Ibid

32 Ibid.
} 
coming properly; now it's a case of do or die. This will at once give a more practical slant to my military studies. I shall apply myself without delay to the existing organisation and elementary tactics of the Prussian, Austrian, Bavarian and French armies, and apart from that confine my activities to riding, i.e. fox-hunting, which is the best school of all. ${ }^{33}$

For the remainder of 1857 and in January 1858, Engels kept Marx apprised of the developments of the crisis, feeding him detailed and confidental information. For example, Engels informed Marx about houses endorsing bills, such as Schunck, Souchay \& Co., and Engels emphasized: "If I give you the names of the houses concerned, it is on the understanding that this remains strictly between ourselves. I could get into a devil of a row if such an abuse of confidential information were to come to light."34 During the deluge of information he provided Marx, Engels was also steering his attention. Engels emphasized the importance of overproduction during the crisis, and urged Marx to pay attention to "how overproduction is generated by the expansion of credit and by overtrading."35 Engels also told Marx what information to squirrel away, notably to "make a note of the balance-sheets of the firms that have failed.... All of them most edifying." 36

Marx exhorted Engels to keep the information coming, to "[w] rite to me whenever you have the time, for later on you're sure to forget all the 'chronique scandaleuse' of the crisis which is so invaluable to us. I make excepts from your letters and enter them in the principal record books." ${ }^{37}$ Marx did save excerpts from Engels's correspondence and used this information in Capital. For example, he virtually copied one later epistolary report by Engels in Capital Volume I. In

\footnotetext{
33 Ibid

${ }^{34}$ Engels to Marx, MECW, v. 40,\#113, December 9, 1857.

35 Engels to Marx, MECW, v. 40,\#114, December 11, 1857.

${ }^{36}$ Engels to Marx, MECW, v. 40,\#115, December 17, 1857.

37 Marx to Engels, MECW, v. 40,\#117, December 21, 1857.
} 
January 1867, Engels provided Marx with information concerning a glut in the cloth market in England that led to selling vast amounts on consignment to India and China, and to renewed tensions in labour relations. The pressures to cut wages (in the long term interest of capitalists), ultimately resulted in an agreement between labor and capital for shorter work days. ${ }^{38}$ Marx, providing no credit to Engels, used this in Capital Volume I as firsthand documentation to bolster his contention that improvements in machinery adversely effected labor ([1867] 1990, p. 561). Notably, Marx often provided no citation information when he described or examined the cotton industry in Capital Volume I--thus, numerous examples and descriptions, and some of these from Engels, appear with no bibliographical information. ${ }^{39}$

During January 1858, Marx and Engels's correspondence about the crisis came to an end. Curious about the state of affairs at Manchester, Marx wrote: "How is business ...? Everything seems to be going better than expected." 40 Engels replied with reports of fox hunting, and of the markets showing signs of improvement. Engels hopes of trading huckstering for militia strategy ended. After what became know as the crisis of 1857, Engels continued to apprise Marx of the tribulations of the cotton market, however, no other market convulsion carried the same prospect again. Engels never again wrote Marx letter after letter sanguinely charting Manchester affairs and expectantly spying signs of the advent of proletarian revolution.

\footnotetext{
38 Engel to Marx, MECW, v. 42, \#207, January 29, 1867.

${ }^{39}$ Engels's firsthand business experience enabled him to provide editorial assistance to Marx for Capital Volume I. For instance, he amended a footnote to a later edition of Capital Volume I that evinced his understanding of the history of the cotton industry (Marx [1867] 1990, 805, fn 35). Engels also added footnotes that required his business expertise. For example, he clarified the distinction between "normal" and "commercial" horsepower ([1867] 1990, 511, fn 25). ${ }^{40}$ Marx to Engels, MECW, v. 40,\#131, January 23, 1858.
} 
How Marx called upon the knowledge of his comrade in arms also changed. After 1857, Marx turned to Engels for help to comprehend some of the bookkeeping practices of Ermen \& Engels in order to better understand what he dubbed the cycle of industrial reproduction - that is the timing of when a bulk of the machinery in industry was replaced. Marx took industrial reproduction as the key to understand crisis. Marking the watershed in their epistolary exchange, Marx, as we will see in the section below, wrote Engels about depreciation calculations in early March 1858. Marx had witnessed the end of an industrial cycle in 1857, and he turned to Engels for guidance to help develop his thinking about crisis for his great writing project, Capital. ${ }^{41}$

\section{Engels's practical knowledge and Capital}

Over the years Marx sought Engels's for his knowledge of business in practice. Marx queried know how of management and bookkeeping: how Ermen \& Engels calculated depreciation; if the firm had an accumulation fund and if so what use it made of it. In these letters, Marx appealed to Engels' authority as an experienced capitalist. For example, Marx wrote that "as a manufacturer, you must know what you do with the returns on capital fixe before the time it has to be replaced in natura. And you must answer this point for me (without theorizing, in purely practical terms)."42 On another occasion, Marx said that "[s]ince practice is better than all theory, I would ask you to describe to me very precisely (with examples) how you run your business." 43 We note that Marx almost always queried Engels about the practices of capital, rarely about the

\footnotetext{
${ }^{41}$ In Capital Volume I, Marx wrote: "It will be remembered that the year 1857 brought one of the gigantic crises with which the industrial cycle always terminates" ([1867] 1990, p. 822).

${ }_{42}$ Marx to Engels, MECW, v. 42, \#243, August 24, 1867.

43 Marx to Engels, MECW, v. 43, \#110, November 14, 1868.
} 
conditions and actions of labor. ${ }^{44}$ This is not surprising given the scope of Engels's duties at Ermen \& Engels.

After the 1857 crisis, Marx began examining the connection between how often machinery was replaced and the length of the industrial cycle. ${ }^{45}$ Marx had studied Charles Babbage's On the Economy of Machinery and Manufactures (1832), wherein Babbage maintained that it would take on average five years for machinery to wear out and require replacement. Babbage had visited factories to gather data to support his claim. Marx, however, suspected that five years was incorrect. Knowing nothing in the British Museum to consult, he turned to Engels's firsthand observations. Engels responded with a lengthy and detailed letter,46 maintaining that Babbage's "assertion is so absurd" and that there is "not a single establishment in England in the regular line of big industry which replaces its machinery in 5 years." According to Engels, "The most reliable criterion is the percentage by which a manufacturer writes down his machinery each year for wear and tear and repairs, thus recovering the entire cost of his machines within a given period.” Engels said businesses normally used a depreciation rate of $7.5 \%$ per annum, and hence assumed the machinery would be paid for over $131 / 3$ years by way of annual deductions from profits. Engels provided Marx with an accounting rule, establishing how the value of machinery would wear out in the books. ${ }^{47}$ Engels also explained in his example balance sheet how the business would make account of expenditures on repairs.

\footnotetext{
${ }^{44}$ There is only one letter where Marx asked Engels about the workers at Ermen \& Engels (MECW, v. 41..351). Engels offered no written reply.

45 Marx to Engels, MECW, v. 40, \#147, March 2, 1858.

46 Engels to Marx, MECW, v. 40, \#148, March 4, 1858, pp. $279-282$.

47 In Capital Volume I, Marx's use of the concept "depreciation" accorded with Engels's business conception. Marx maintained that the value the machine transfers to the product equals depreciation (p. 509). Marx also maintained that machinery created no new value; it "never adds
} 
The figure of $131 / 3$ was an accounting convention, and Engels cautioned Marx that in reality business often proceeded quite differently, that "numerous bankruptcies and changes occur; you may enter other branches, sell your old machinery, introduce new improvements." Engels said the Ermen \& Engels's mill had 20 year-old machines still in operation, and some of "the more ancient and ramshackle concerns" contained parts at least 30 years old. The matter was further complicated because the durability of machines and the ease of replacing parts made it possible for legacy machinery to incorporate new innovations. He reported that "over the last 20 years improvements in spinning machinery have not been such as to preclude the incorporation of almost all of them in the existing structure of the machines, since nearly all are minor innovations." [emphasis by Engels] Despite the difficulties in tracing reproduction in kind (and recording the death and integrity of machines as material objects) Engels trusted the wisdom of business and that if his $131 / 3$ "calculation wasn't more or less right, practice would have changed it long ago." Engels closed his letter with a telling observation about obsolescence that: "Ten to twelve years are enough to bring about changes in the character of the bulk of machinery, thereby necessitating its replacement to a greater or lesser extent."48

Marx's reliance on a 20 year old text by Babbage suggests how difficult it was for him to peer into the opaque business practices of Manchester capitalism

more value than it loses, on average, by depreciation" (p. 509). Marx's position here followed the conventional business practice of his day.

${ }^{48}$ Engels's letter posed a challenge to Marx. Engels stated that Ermen \& Engels had twenty year old machinery in operation, and Marx maintained that the cycle of industrial reproduction was far shorter than this. Hence, Marx needed to address how to determine the value transferred from machines that operated for long periods of time. To do so, Marx maintained that an operative machine's exchange value depended upon the creation of new and improved machinery of less value, and that the value of an operative machine depended upon the labor time necessary to produce the superior machine ([1867] 1990, p. 528). Marx dubbed the loss in value of the superior "moral depreciation." 
from the shelves of London libraries and hence Engels's rich response was

informative and authoritative. In his reply, Marx stated

My best thanks for your éclaircissements' about machinery. The figure of 13 years corresponds closely enough to the theory, since it establishes a unit for one epoch of industrial reproduction which plus ou moins coincides with the period in which major crises recur; needless to say their course is also determined by factors of a quite different kind, depending on their period of reproduction. For me the important thing is to discover, in the immediate material postulates of big industry, one factor that determines cycles. ${ }^{49}$

Marx's reply reveals determining the periodicity of crises was paramountindeed his March 1858 letter came shortly after the late 1857 crisis. In Capital Volume II, Marx maintained that industry and industrial capital had a lifespan, and in accord with Engels's letter, he asserted that innovations influenced this lifespan due to invention and competition-means of production had to be updated long before they were worn out. Regarding the life cycle of industry, Marx agreed with Engels: "We can assume that, for the most important branches of large-scale industry, this life cycle is now on average a ten-year one" ([1885] 1992, p. 264)..$^{50}$ Furthermore, Marx tellingly maintained that industrial capital provided the "material foundations" for the "periodic cycle" or crisis, and the crisis "is always the starting-point of a large volume of new investment." (Below we will show this crucially depends on the accumulation fund.)

Alongside this conversation about the lifetime of machines, Engels was Marx's source for data on depreciation calculations for use in Capital Volume I. ${ }^{51}$ Apparently Marx could not find this information anywhere else. On p. 186 in the

\footnotetext{
${ }^{49}$ Marx to Engels, MECW, v. 40,\#149, March 5, 1858.

${ }^{50}$ Interestingly in Capital Volume III, Engels used the ten-year average (as Marx does on this page of Capital Volume II) for the crisis cycle. See p. 633 (pdf version??????). Marx also used the tenyear figure in Capital Volume III; see for example pages: 280 and 345.

${ }^{51}$ Engels to Marx, MECW, v. 43, \#17, May 10, 1868.
} 
original German edition, Marx included a table based on data that Engels had given him culled from Ermen \& Engels's books. ${ }^{52}$ In 1868, when working on the second edition of Capital Volume I, Marx wrote again to Engels to obtain additional data to supplement the table. ${ }^{53}$ Subsequent editions of Capital include that information, presumably provided by Engels; see Marx ([1867] 1990, 327328). Marx used the data to provide an example on how to calculate the rate of surplus value, that is the ratio of surplus labor to necessary labor. The details in the example include: the price of cotton, cost per spindle, wage cost per spindle, wages, depreciation, price of yarn, and more. He admitted in a footnote that the example in the first German edition contained some factual errors. He said the updated example was "entirely accurate'" and credited a "Manchester manufacturer" ([1867] 1990, 328, fn 8).

A few years after their correspondence on machinery Marx was again seeking Engels's insight into business practice when he wrote asking about the existence of the accumulation fund and how it was used.54 Marx defined the accumulation fund as a fund of money dedicated to replacing worn out machinery. Marx stated that the political economy literature, namely the Malthusians, acknowledged the existence of the accumulation fund, but provided no indication of its business use. Marx insisted that the response he sought from Engels was how the fund was used "in practice."55 That Marx wrote to Engels on this subject in 1862 and in 1867 suggests how important he saw the accumulation fund for his analysis. In 1862, Marx wanted to know if a business actually used an accumulation fund; he said that as a businessman, Engels "must

\footnotetext{
52 Marx to Engels. MECW, v. 43, \#19, May 16, 1868.

53 Marx to Engels., MECW, v. 43, \#15, May 7, 1868.

${ }^{54}$ Marx to Engels, MECW, v. 42, \#243, August 24, 1867

55 ibid
} 
have the answer." ${ }^{56}$ Notably, Marx thought if businesses actually used an accumulation fund, this fact might help explain why in developed capitalist economies capital accumulated at different rates. Engels wrote a short reply in 1862, and said he was far too busy at Ermen \& Engels to answer in full. ${ }^{57} \mathrm{He}$ suggested, however, that Marx would benefit from his business expertise because he suspected Marx had missed or misunderstood something—Engels did not specify what.

Engels's response to Marx's second attempt in 1867 was more forthcoming, although he did not answer at once, excusing himself to "ask some other manufacturers whether [Ermen \& Engels] practice was the customary one or an exception." 58 The response was detailed, with two long tables to illustrate the reasoning. It was an abstract example and not a rendition of actual experience. At the start of his letter, Engels reminded Marx of the 7.5\% rate of depreciation that was best practice but instead used a $10 \%$ rate for ease of exposition. Engels then outlined two scenarios linked to his two schedules. The first assumed that the manufacturer invested all the money he wrote off over the life of the machine into the money markets until the time it was needed to replace the equipment in full. Engels showed that if a capitalist earned 5\% annual interest on the $10 \%$ yearly write off of 1000 pounds of machinery, then he would end up with a little over 1250 pounds in "ready cash" at the end. The second scenario, that reflected Ermen \& Engels practice of continuous improvement in machinery, was more advantageous. The manager would purchase new machines each year in the value of the write off, on the first

\footnotetext{
56 Marx to Engels, MECW, v. 41, \#243, August 21, 1862.

${ }^{57}$ Engels to Marx, MECW, v. 41, \#247, September 9, 1862.

58 Engels to Marx, MECW, v.42, \#244, August 26, 1867.
} 
instance only as a portion of the 1000 pounds but later also on the reinvested stock. Over the ten years of compounded renewal, the value of the machine stock at the start and the end would be the same 1000 pounds, but throughout the period the firm would have been working at higher capacity. Engels emphasized that "the money advanced for writing off has thus enable [the capitalist] to increase his machinery by $60 \%$ [over the ten years] and without putting a farthing of his actual profit into the new investment." In the example the capitalist had on average $45 \%$ increased capacity. ${ }^{59}$ In sum, Engels demonstrated to Marx that the capitalist used the accumulation fund (what he called "renewal fund") in two different ways: either as investment, thereby accruing interest and hence amassing wealth for later use, or as a means to continuously replenish and expand machinery, thereby immediately enabling increased production for the business. Marx seemed satisfied with the explanation of how the accumulation fund was used to expand business and replied with the shortest of thanks. 60

Marx wrote about the "accumulation fund" in Capital Volume II ([1885] 1992, 158, 250-251).61 He first recapitulated his understanding of depreciation as stated in Capital Volume I: the portion of value of fixed capital that a machine transfers to the product equaled depreciation. Then Marx maintained that some kinds of fixed capital, due to natural wear and tear, had to be replaced in part each year. His example was the railway industry where replacement approximately equaled the amount of depreciation each year. However, in other industries, Marx maintained that the value of depreciation could be made into a

\footnotetext{
${ }^{59}$ Engels to Marx, MECW, v.42, \#245, August 27, 1867.

${ }^{60}$ Engels to Marx, MECW, v.42, \#248, August 31, 1867.

61 Note that Marx did not use the term "accumulation fund." He called it a "reserve fund."
} 
money fund. In the following, Marx echoed Engels and offered the striking

implications of the accumulation fund:

Even though, as we have seen, the fixed capital continues to function in its natural form in the production process, if a part of its value has circulated with the product, according to the average wear and tear, and been transformed into money, then is forms an element of the money reserve fund for the replacement of the capital when its reproduction in kind falls due. This part of the fixed capital value transformed into money can therefore serve to expand the business or to effect improvements in the machines which increase their effectiveness. ...This reproduction on an expanded scale does not arise from accumulation-the transformation of surplus-value into capital-but from a retransformation of the value, which branches into two parts, and in its money form has separated itself off from the body of fixed capital, into new fixed capital of the same kind, either additional or more effective. Of course it depends in part on the specific nature of the business how far and in what dimensions it is susceptible to a gradual addition of this kind (p. 251).

Marx saw the potential in certain industries for expansion through the accumulation fund, and maintained that this expansion did not have to depend on profits. Marx surely had Ermen \& Engels in mind when he wrote this. Thus Marx suggested that certain industries could weather crises better than others, and that at the end of the industrial reproduction cycle when a crisis ensued, certain industries would be better poised to expand.

The attention given to the accumulation fund in Capital Volume II is significant. One of the main points in Capital Volume I is that machinery gradually and eventually displaces workers; in chapter fifteen Marx showed this was the case historically. In Capital Volume II, Marx suggested that as the use of the machinery grew, the industries that employed those machines could use the accumulation fund to increase the scale of industry. And the larger the scale of machine-based industry, the greater the potential of the accumulation fund to further increase the scale. Thus the accumulation fund proved crucial to the 
industrial reproduction cycle, and would have provided the capitalist with the means to invest post-crisis.

There is no evidence that Engels criticized Marx's understanding of the depreciation of machinery and the accumulation fund expressed in Capital. As reviewer and copy editor of volume I, and as editor of volume II - a five-hundred page manuscript found in 1883 - Engels had ample opportunity to align Marx's writing with his own understanding of business calculations and practices. ${ }^{62}$ Engels corrected Marx in only one instance, taking great pains to substantially revise chapter fifteen, "The Effect of Circulation Time on the Magnitude of Advanced Capital" of Capital volume II. In his assessment Marx had made multifarious mistakes in computing turnover calculations for the circulation of capital. He excused Marx for not being a man of "practical calculations."63 despite his "firm grasp of algebra, he was never at ease in reckoning figures, i.e., commercial calculations." Marx worked through volumes of examples, but "knowledge of the proper rules of calculation is not at all the same thing as exercise in the everyday practical calculations of the trader." ([1885] 1992, p. 359). However much he practiced at his London desk, Marx could not make himself into a Manchester clerk. Engels remained indispensable and irreplaceable as Marx's correspondent in the heart of capitalism. It was in epistolary conversation that Marx gained insight into the formulas of depreciation and the uses of the accumulation fund, unfortunately this schooling never addressed the matter of turnover calculations.

\footnotetext{
62 Engels to Lafargue, MECW, v. 46, \#256, April 25, 1883. Notably, when Engels learned out about the five-hundred page manuscript, he was not aware of its condition (Ibid.). 63 After 1868, Marx did not write Engels again about turnover calculations.
} 


\section{Conclusion}

The traces of the business origins of Marxism faded quickly. A few years after Engels's retirement the firm Ermen \& Engels disappeared. Engels agreed with Godfrey in 1870 that the firm continue to use his family name for five more years, a privilege that under English law exposed him to personal liability. After that time Engels gleefully withdrew his name and the firm was renamed as Ermen \& Roby. Curiously in 1896, within a year of Engels' death, the firm was incorporated with a capital of 134 thousand pounds and a year later was amalgamated with thirteen other firms to form the English Sewing Cotton Company (Henderson 1971). The cotton industry as a family affair died with Engels. The business career of Engels has remained interesting only as an explanation for his wealth and not as a significant fact about his personality, skills and knowledge. Engels bears responsibility for this obfuscation. He never hid his bourgeois origins but always treated these with contempt, and that sentiment contaminated his understanding of his partnership with Marx. Engels wrote that

I cannot deny that both before and during my forty years' collaboration with Marx I had a certain independent share in laying the foundations of the theory, and more particularly in its elaboration. But the greater part of its leading basic principles, especially in the realm of economics and history, and above all their final trenchant formulation, belong to Marx. What I contributed-at any rate with the exception of my work in a few special fields-Marx could very well have done without me. What Marx accomplished I would not have achieved. Marx stood higher, saw further, and took a wider and quicker view than all the rest of us. Marx was a genius; we others were at best talented (Engels 1886[2009], footnote, pp. 41-42).

The followers of Marx and Engels sanctioned this modest assessment conceiving

Engels as a proselytizer or elaborator. 
Our contention that Marx owed much to Engels is however not wholly novel. Gareth Steadman-Jones's writing in 1977 claimed Engels as “co-founder and elaborator of historical materialism" (p. 77). in a plea to devote closer consideration to the insights contained in Engels' Outline and Condition. But no one has yet sought to extend the credit and influence beyond the 1850s and into the Manchester exile. The difficulty, as we have shown, is that those years can be gleaned only in fragments, with Engels purposively drawing a curtain between his business and private life and seeking to preserve only the memory of his radical endeavors.

As we have shown, Capital would have been incomplete without Engels's epistolary insights. His position at Ermen \& Engels allowed him to supply Marx with critical information that Marx could not have obtained elsewhere. Ermen and Engels' business depended upon sound use of machinery valuations and the accumulation fund.

To further detect Engels's imprint on Capital one should also appreciate Engels's more subtle contribution. In numerous newsy paragraphs that intruded on the correspondence about family or European political intrigue, Engels kept Marx abreast of the sentiment of markets, giving him greater access to the views and reactions of capitalists than Marx might glean from reading the Manchester Guardian or The Economist.

It was by Engels' hand that Marx came to see capitalism as engaging a global market and threatened by crises of overproduction. They saw this conception confirmed by the slump of 1857 and the "cotton famine" of a few years later. The anatomy of sudden mass bankruptcy and short time, and also of recovery and prosperity, made the industrial cycle into a fundamental puzzle for 
Marx work. And the key to deciphering it was not to be found in the theory of value but in the dynamics of accumulation. As Marx explained to Engels, "there is a wide divergence in political economy between what is of practical interest and what is theoretically necessary, so that one cannot even find the necessary material."64 It was in that context that Marx called upon Engels's business experience to grasp the practices of machinery valuation and investment. Indubitably, the relationship between Marx and Engels was unique. Singular both for the personalities and life stories of the pair, as for their lasting, world changing, influence. But their partnership is also conventional in many ways. It is cut through by banal family feuds and loyalties and by financial and health worries. It is bond by mid-century cultures of writing and reporting on business, with ideas, clippings of newspapers, and broker circulars moving at impressive regularity through Britain's postal system. And finally, Marx and Engel's intellectual partnership speaks anew to the well known struggle to abstract the experience of lived business into a political economy.

\section{BIBLIOGRAPHY}

Engels, Friedrich 1886 [2009] Ludwig Feuerbach and the End of Classical German Philosophy. London: Union Books.

Hunt, Tristram 2010. Marx's General: The Revolutionary Life of Friedrich Engels. New York: Macmillan.

${ }^{64}$ Marx to Engels, MECW, v. 43, \#19, May 16, 1868. 
Henderson, W. O 1971. "The Firm of Ermen \& Engels in Manchester" Internationale wissenschaftliche Korrespondenz zur Geschichte der deutschen Arbeiterbewegung. 11/12, S. 1-10.

Illner, Eberhard 2012. “Das Textilunternehmen Engels in Manchester. Wirtschaftsbeziehungen und Arbeiterverhältnisse". in Marx-Engels-Jahrbuch 2011, Berlin, pp. 94-112.

Jenkins, Mick 1951. Friedrick Engels in Manchester. Manchester: Lancashire and Cheshire Communist Party.

Kapp, Yvonne 1972. Eleanor Marx. Volume 1: Family Life, 1855-1883. London: Virago.

Kisch, Herbert. 1959. "The Textile Industries in Silesia and the Rhineland: A Comparative Study in Industrialization" The Journal of Economic History Vol. 19, No. 4, pp. 541-564.

Knieriem, Michael 1980. “Die Brüder Ermen in Manchester. Biographische Anmerkungen zu Friedrich Engels' Geschäftspartnern" Jahrbuch des IMSF 3. Frankfurt am Main, S. 312-320.

Knieriem, Michael 1986. "Die Firma Ermen \& Engels" in Manchester und Engelskirchen im 19. Jahrhundert." Marx-Engels-Jahrbuch. 10, Berlin S. 211-234 
Marx, Karl 1990 [1867] Capital, volume I. New York: Penguin.

Marx, Karl 1992 [1885] Capital, volume II. New York: Penguin.

Marx, Karl 1975- Karl Marx, Frederick Engels: Collected Works. (multiple volumes) London : Lawrence \& Wishart.

Mayer, Gustav 1936. Friedrich Engels, A Biography. Chapman \& Hall.

Rose, Mary B. 2000. Firms, Networks and Business Values: The British and American Cotton Industries since 1750. Cambridge: Cambridge University Press.

Scott, Robert D. H. 1976. The biggest room in the world. Manchester: Royal Exchange Theatre Trust.

Steadman-Jones, Gareth 1977. "Engels and the Genesis of Marxism” in New Left Review, November-December, n. 106.

Whitfield, Roy 1988. Frederick Engels in Manchester, The Search for a Shadow, Manchester Free Press.. 